\title{
Unmanned Aerial Vehicles for Civil Engineering: Current Practises and Regulations
}

\author{
Sadik Alper Yildizel*, Gokhan Calis ${ }^{2}$ \\ ${ }^{1}$ Karamanoglu Mehmetbey Üniversitesi, Mühendislik Fakültesi, İnşaat Mühendisliği Bölümü, Karaman, Türkiye (ORCID: 0000-0001-5702-807X) \\ ${ }^{2}$ Karamanoglu Mehmetbey Üniversitesi, Mühendislik Fakültesi, İnşaat Mühendisliği Bölümü, Karaman, Türkiye (ORCID:0000-0001-7196-9407)
}

(First received 15 May 2019 and in final form 20 August 2019)

(DOI: 10.31590/ejosat.565499)

ATIF/REFERENCE: Yildizel, S. A. \& Calis, G. (2019). Unmanned Aerial Vehicles for Civil Engineering: Current Practises and Regulations. European Journal of Science and Technology, (16), 925-932.

\begin{abstract}
Lately, Unmanned Aerial Vehicles (UAVs) have been widely preferred in construction industry, and their applications are changing the way construction companies work. Yet, the productivity gap between manufacturing and construction is very high. With the help of UAV's, construction productivity can be developed. UAV's has may benefits for the civil engineering discipline and many various applications from inspection of any on-site activity to personal safety operations in construction projects. Site progress can be easily tracked by them and furthermore surveying can be done very fast withous having people at site where might be dangerous. Eventhough current practices of UAV's use are limited, in the near future this will change not only in construction industry. Drones are gaining popularity not only locally but globally among the stakeholders including clients, contractors and consultant engineers for assessing complex and and detailed situations. Use of UAV's enables project management professionals understand the problems,making decisions fast and taking required immediate actions. However, state and local regulations are limiting their usages and efficiencies. Construction companies must be aware of the regulations and risks in order to apply UAV technology to their projects. This paper aims to investigate the current practices of UAVs in construction industry by revieweing the publishes academic papers. Furthermore the different regulations set regarding use of drones in different countries different countries and regions such as USA, EU,China and Turkey are also investigated. This research also comprises some legal recommendations to the Turkish authorities which might be beneficial to establish a solid structure for UAV's.
\end{abstract}

Keywords: UAVs, construction, regulations, Turkish regulations, comparison.

\section{İnşaat Mühendisliğinde İnsansız Hava Araçları: Mevcut Düzenlemeler ve Uygulamalar}

\section{Öz}

Son zamanlarda, İnsansız Hava Araçları (İHA) inşaat endüstrisinde yaygın olarak tercih edilmiştir ve uygulamaları inşaat şirketlerinin çalışma şeklini değiştirmektedir. Ancak, üretim ve inşaat arasındaki verimlilik açığı çok yüksektir. UAV'lerin yardımıyla, inşaat verimliliği geliştirilebilir. İHA inşaat mühendisliği disiplini ve şantiye faaliyetlerinin denetlenmesinden inşaat projelerinde kişisel güvenlik operasyonlarına kadar birçok uygulama için fayda sağlayabilir. Sahadaki ilerlemeler onlar tarafindan kolayca izlenebilir ve ayrıca sahadaki kişilerin tehlikeli olabileceği yerlerde bulunan kişilerle çok hızlı bir şekilde araştırma yapılabilir. Nihayet UAV'ın kullanımına ilişkin uygulamalar sınırlıdır, ancak yakın gelecekte bu sadece inşaat sektöründe değişmeyecektir. Dronlar, hem yerel hem

\footnotetext{
* Corresponding Author: Karamanoglu Mehmetbey Üniversitesi, Mühendislik Fakültesi, İnşaat Bölümü, Karaman, Türkiye, ORCID: 0000-00015702-807X, sayildizel@kmu.edu.tr
} 
de global olarak, karmaşık ve ve detaylı durumları değerlendirmek için müşteriler, müteahhitler ve danışman mühendisler dahil paydaşlar arasında popülerlik kazanıyor. UAV'lerin kullanımı, proje yönetimi uzmanlarının sorunları anlamasını, kararları hızlı bir şekilde almasını ve gerekli acil önlemleri almasını sağlar. Bununla birlikte, eyalet düzenlemeleri ve yerel düzenlemeler kullanımlarını ve verimliliklerini sınırlamaktadır. İnşaat şirketleri, İHA teknolojisini projelerine uygulamak için düzenlemelerin ve risklerin farkında olmalıdır. Bu makale, İHA'ların inşaat sektöründeki güncel uygulamalarını yayınlayarak akademik makaleleri inceleyerek incelemeyi amaçlamaktadır. Ayrıca, farklı ülkelerde dronların kullanımıyla ilgili farklı düzenlemeler ABD, AB, Çin ve Türkiye gibi farklı ülke ve bölgelerde de incelenmektedir. Bu araştırma aynı zamanda, Türk makamlarına İHA'lar için sağlam bir yapı oluşturmada faydalı olabilecek bazı yasal öneriler de içermektedir.

Anahtar Kelimeler: İHA, inşaat, Türk düzenlemeleri, karşılaştırma.

\section{Introduction}

In terms of definition, an UAV is a flying aircraft without any pilot or passengers. UAVs are either remotely controlled through computer aided flight routes with the sensors or autonomously. They are generally equipped with a high-resolution camera for video broadcasting and recording(Rao, Gopi, \& Maione, 2016). The first use of drones can be traced back to the $18^{\text {th }}$ century. Unmanned balloons were used in France. Later on, USA intelligence agencies and military forces started to use UAVs for military operations in the early 2000's(Aydin, 2019). Nowadays it is accessible to amateurs and commercial users in many types and price in the market. As of today, they are widely operated for civilian aims such as weather and traffic monitoring, and videography (Farber,2014). UAVs are designed over on existing aircrafts and they have different shapes. Among the other types, the military drones are the most expensive models. The prices in the market ranges from \$200 to \$45,000 depending on their payload options and the systems (Siebert,2014). Civilian drones can be classified into four main models: multi-copters, airships, fixed wing UAV and rotary blade UAV (Fig.1) (Wang,2016). The Table 1 summaries the limitations and the advantages of these four drone types.
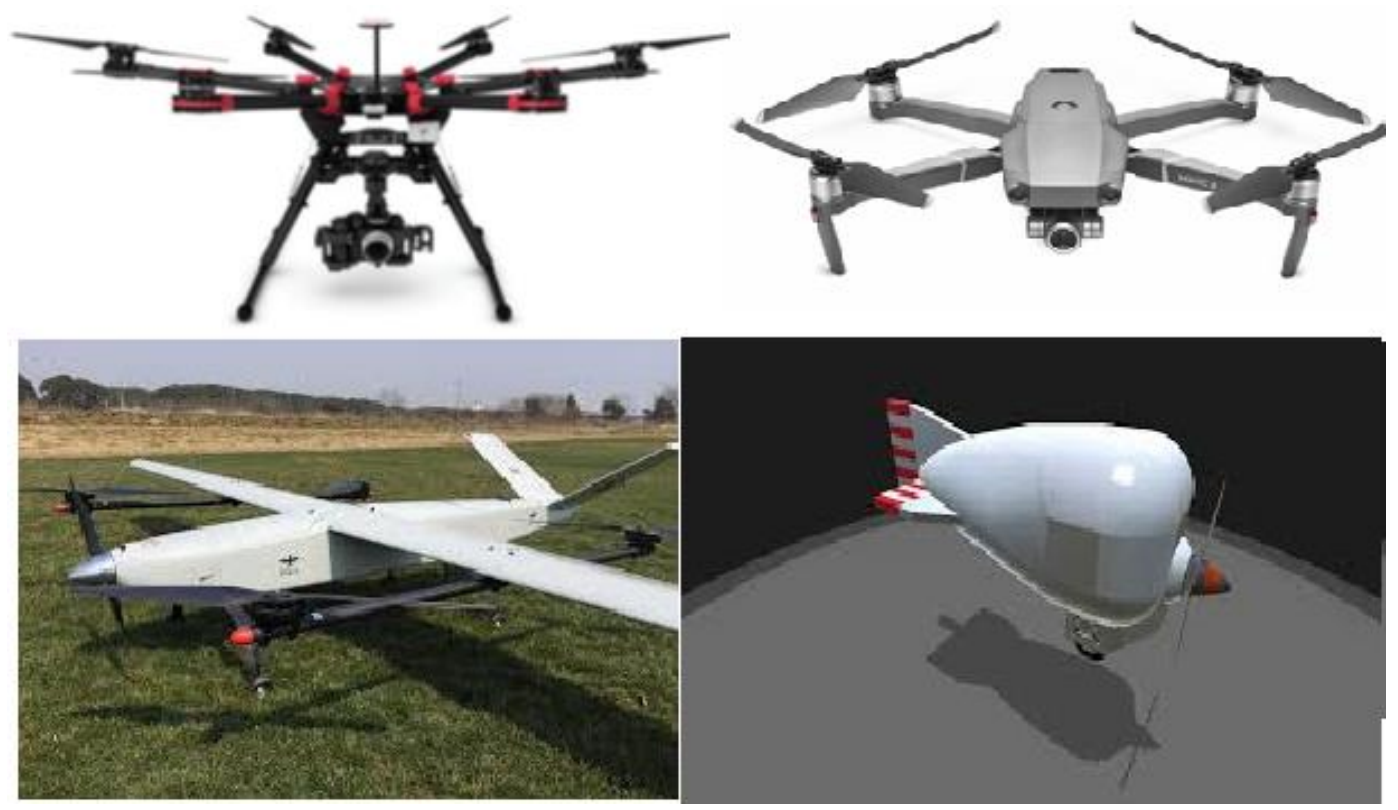

Figure 1. Various types of UAV

Until end of the 1990's police Manned Aerial Vehicles (MAV) were operated by the police and medical services for providing live information or first aid purposes until the end of the 1990s. However currently UAV's replaced manned MAV's in the high risk and cost operations. Instead of endangering a helicopter by sending to hostage situation to gather intelligence, now UAV's are used(Anania et al., 2019). Furthermore, in daily operations such as monitoring the traffic flow UAV's provide police substantial information (Barmpounakis et. Al,2016).

Table 1. Comparison of UAVs (Siebert and Teizer, 2014)

\begin{tabular}{|l|l|l|l|l|}
\hline UAV type/ Features & Multi-copters & Rotary blade UAV & Fixed wing UAV & Airships \\
\hline Range & Poor & Average & Very Good & Very Good \\
\hline Flexibility & Very Good & Very Good & Poor & Average \\
\hline Weather dependency & Good & Good & Good & Poor \\
\hline Payload & Average & Very Good & Good & Very Good \\
\hline Safety & Average & Poor & Average & Good \\
\hline Complexity & Good & Poor & Average & Good \\
\hline Operation cost & Very Good & Average & Average & Poor \\
\hline Set up time & Very Good & Good & Average & Poor \\
\hline
\end{tabular}


The productivity gap between the construction sector and other industries increased approximately $70 \%$ in the last decade (Changali, et al. 2015). One of the main reasons is that other sectors have been efficiently using integrated information systems. Similar systems such as Building Information System (BIM) has been widely preferred by the construction industry; however, this system do not reflect the real-world situations in a construction project like construction material and the cost. For this reason, they are more suitable for design and design related works. The efficiency gap should be filled with other technologies for the construction industry (Dupont et al., 2017).

Even though UAV's have been widely used in various industries for varies reasons UAVs, currently are not able to perform any construction activities(Kavoosi et al., 2018). However, they are very useful for collecting live data, collecting surveying data (Zhang and Singh,2014). Manned systems can be replaced to obtain accurate and live data collection. Apart from the beneficial part of the use of the UAVs, there are also issues like battery limitation and payload balance problem to be solved. Many academics have been working for improving these negative sides of the UAV usage (Floreano and Wood, 2015).

Flying drones are classified into two main categories for data collecting eyes: having laser based and mono stereo cameras. Laser based systems are not the cheapest and efficient solution for accurate data. Since supporting systems like 3D model creation tools are also required for obtaining aimed construction data (Nex and Remondino, 2014). Available UAVs missions during the design and construction phases are to scan the landscape of the site in 3-D view. The main purpose for design phases is to obtain integrated landscape of the project site by the aid of 3-D modelling software. Providing bird-eye view of the on-going project is the main goal of the operation of the UAVs in the time of all construction phases (Skycatch, 2017). Regular and autonomous monitoring of construction project is still performed by man based workforces with the help of various forms, schedules and photographs. Moreover, all collected data are not successfully and consistently integrated into any construction management systems. Several researches on the use of BIM platform has been conducted for a better integration (Cladas, Soibelman and Gasser, 2005). For collecting data parts, UAVs can be replaced efficiently with the human efforts (Goedert and Meadati, 2008).

Some current practices of the drone usage in civil engineering discipline all over the world are exampled as follows:Sacramento stadium construction activities were monitored by a flying drone from the commencement day to hand-over date. This management preference eases the weekly and monthly planning works and allow to foresee the potential risks before they occur (Koon,2015). Joint ventures like Komatsu-Skycatch and Caterpillar-Redbird used UAVs in their projects as having the bird-eye view of their project. After the receipt of on-site live and accurate data, they could right orders to construction robots to perform their tasks (Lavoie,2015;BBC,2016). Despite these breathtaking applications, many projects are executed for military purposes today (Chen, 2010; Cheung and Grocholsky,2008). When monitoring large-based projects as dams and airports, using an air drone becomes a productive selection depending on its mobility ( Morgenthal and Hallerman, 2014). A road condition assessment, especially on mountain roads was reported within the limit of $0.50 \mathrm{~cm}$ accuracy (Vilariona,2016). Currently drones are not used in carrying loads in construction. However, in the near future with the development of technology they will be able to carry construction items to the high points. Addition to that, instead of having people working at height, drones will be able to weld steel which will save time and energy and also reduce the risks significantly. Considering these potential developments and use of UAV's in construction industry, the regulations should be investigated deeply and regulations should be stuctured in a way that sufficient to the needs and cover all the legal gaps.

\section{Drones in Construction}

Construction industry was critised many times by the researchers as, it is not as productive as manufacturing industry(Egan, John, 1998). New technologeis are helpful tools to increase productivity of construction. Drones are used in construction site with various purposes such as; collecting data and monitoring the progress (Dobson et al.,2013). Drones can be very useful in helping project management team to follow the project progress daily (Yamomto et al.,2014). It is very equipment that gives access to the whole site. They are not providing only images but also volumetric reports as well (Anwar, Naveed Asian Institute of Technology, Izhar, Muhammad Amir, Kabot Systems Ltd, Najam, Fawad, 2018; Bognot, Candido, Blanco, Rene, \& Montelibano, 2012).

Table 2: Literature review of UAV's in construction

\begin{tabular}{|l|l|}
\hline Purpose & Reference \\
\hline Progress monitoring & $\begin{array}{c}\text { (Han et al. 2015) (Lin, Han \& GolparvarFard } \\
2015) \text { (Zollmann et al. 2014) (Kluckner et al. 2011) }\end{array}$ \\
\hline Site monitoring & (Wen et al. 2014) (Yang et al., 2015) \\
\hline Building Inspection & (Wefelscheid et al. (Michael et al. 2014)) \\
\hline Building measurement & (Xie et al. 2012) \\
\hline Surveying & (Siebert \& Teizer 2014) (Fiorillo et al. 2012) \\
\hline Safety inspection & (Gheisari et al. 2014; Irizarry et al. 2012) \\
\hline
\end{tabular}




\section{Ethical, Privacy and Safety Issues}

As commonly accepted, there are clear beneficiaries for using UAVs in civil projects. However, some journalists, society organizations and academics utter their concerns about their deployments. The utilization of UAV's in terms of ethics and privacy may cause a threat to civil liberties, although safety requirements take first place for regulations (Finn andWright, 2012).

In Europe, the utilization of UAVs is regulated by the Charter of Fundamental Rights. According to the articles of this charter, a person has a right to respect for their private life, communications, home, and an individual has the right of protecting his or her own personal data. In the UK, if the recorded data is not interfered with the person's private life, it is lawful according to the Charter of Fundamental Rights (Williams,2008).

In the USA, American law preserves human rights. The Fourth Amendment of the US Constitution protects American citizen from antithetical searches in where a person has a reasonable expectation of personal life. There is a lot of debate about the law of the usage of UAVs. Both emphasizes that if ever UAVs are in public use, the protection can be nullified (Finn andWright, 2012).

Apart from the safety concerns, there has been live debate on the ethical use of UAVs in war operations. The operators have been blamed for killing soldiers from human consequences of the actions. The potential use as a weapon brings about the more safety and ethical concerns concerning the right to life.

Some academics debate that drones' usage raises the public concerns, since everyone gets tracked, photographed and targeted. This situation is counted as disrespectful action to one's private life. There are many news articles about upset property owners whose privacy were invaded by drone operators. Invasion of privacy has been a long issue tied in capturing geographic information via satellite, airplanes of UAVs and it turns into a special subject when the image is taken from a private property.

Allowing commercial use of UAVs is full of ethical issues. In addition to above mentioned privacy issues, commercial use of drones may take away lots of jobs and create un-employment or decrease wages.

Safety inspection is count as a vital element of safety management systems for early detection and correction of the risks. Number of accidents can be lowered by strict implementation of safety regulations in a construction site. In other words, accidents and occupational illnesses rate increased without any safety related precautions. Some academics performed initial evaluation of UAVs potential for assisting safety management works on the construction sites. In the first study, A Heuristic Evaluation (HE) was used as the first step for the evaluation due to its basic user interface and availability. This basic methodology was developed by Dix et al. in 2004 . Further and more detailed case study related to the use of UAVs for safety inspection. However, valuable data related to the on-site safety conditions were obtained during this study. Effective flights for safety inspection can be easily obtained if the required permissions are granted by the local authorities. The research outcomes were summarized for contributing the decision-making phases and enhance the effectiveness of the safety inspections in Table 3 (Dix, Finlay,Abowd and Beale,2004).

Table 3. UAV applicability for Safety Inspections (Dix, Finlay,Abowd and Beale,2004)

\begin{tabular}{|l|l|l|}
\hline Aspects & Advantages & Barriers \\
\hline UAV procedure and planning & Identification of safety point of interest & Weather conditions \\
\hline Data gathering and processing & $\begin{array}{l}\text { Less time spent during inspection as } \\
\text { multiple activities can be monitored } \\
\text { simultaneously. Simplified inspection } \\
\text { stages due to less time spent in manual } \\
\text { data gathering. } \\
\text { Easiness of using technology ; Data } \\
\text { standardization, reducing variability }\end{array}$ & $\begin{array}{l}\text { Laws } \\
\text { requirements; } \\
\text { UAS Training for pilot/observer }\end{array}$ \\
\hline Data analysis and processing & $\begin{array}{l}\text { Enhance of the transparency of the unsafe } \\
\text { conditions; Detailed information about } \\
\text { unsafe and safe conditions; Use of } \\
\text { indicators and information for decision } \\
\text { making; Use of the visual assets and the } \\
\text { results from inspection } \\
\text { for safety education }\end{array}$ & $\begin{array}{l}\text { Need to improve real time feedback for } \\
\text { workers; } \\
\text { safety personnel'. }\end{array}$ \\
& $\begin{array}{l}\text { UAS Cost-benefit feasibility; } \\
\text { Possible development of employers' } \\
\text { safety attitudes. }\end{array}$ & $\begin{array}{l}\text { Resistance to the adoption of new } \\
\text { technologies; } \\
\text { Poorly structured safety management } \\
\text { system on jobsite }\end{array}$ \\
\hline Staff and system
\end{tabular}


Results of abovementioned study suggested that, there was a great potential of using UAVs as a safety monitoring vehicle on a construction projects.

\section{Global UAV Regulations and Turkish Law}

With the raising of new technologies in the UAV industry, it becomes very important to evaluate all existing and new regulations around the world. Lately, new regulations have been introduced to the drone operation market for making easier commercial and personal applications of UAVs.

The Federal Aviation Agency distinguishes UAV usage intent as recreational and commercial. Recreational usage is limited since the probability of any involvement unrelated to the one's occupation. If a drone used is for recreational purposes, FAA approval is not required, but the drone must be in the limit of visual line of sight, comply with the required safety guidelines and 5 miles away from the airports. In addition, the UAV must be less than 55 pounds. UAV usage intent can be accepted as a commercial one, if there exists a relationship between the operator occupation and the use of drone. These new rules still ban the UAV from being operated over people and a moving vehicle. This ability carries a significant importance, especially for construction industry for wide ranges of objectives such as monitoring productivity and safety when the site is occupied.

In European Union, the International Civil Aviation Organization (ICAO) regulates the all civil aviation European Aviation Safety Agency (EASA) develops UAV regulations under the command of ICAO. Drones weighing more than $150 \mathrm{~kg}$ directly regulated by ICAO; however, UAVs within the weight limit of $150 \mathrm{~kg}$ were regulated by each nation. European Union is currently working on balancing the usage of UAVs in many applications while having these five objectives (Heredia et al.,2009):

- Support the development of UAV market.

- Ensure security.

- Maintaining safety of EU aviation.

- Respect the rights of protection of personal data, private and family life.

- Ensure the risk fee depending on the usage of UAVs.

European Union's regulations are more relaxed, and free to decide depending on the country, in comparison. French laws are making it easier and clear for commercial drone operations. The current limitations are as follows (Okrent,2004)

- The UAVs must be in the limit of visual line of sight of the operator.

- All flights must be under the altitude of $500 \mathrm{ft}$.

- The operator must avoid flying drones over people.

- All operations must take place during the day.

In 2015, South African Civil Aviation Authority released a new set of rules and these regulations state (Ingham, Jones and Maneschijn,2006):

- $\quad x$ All UAVs must be operated under the altitude of $400 \mathrm{ft}$.

- The drone must be maximum 500 meters way from the operators.

Turkish regulations are more rigid compared to the global legislation and rules. In 2016, General Directorate of Civil Aviation released latest rules and some limitations are as follows:

- Before the flight, permissions must be granted by the local authorities.

- The flights must be $9 \mathrm{~km}$ away from the airports.

- No flight permitted around the military buildings, national defence industry factories, prison buildings.

- The weight of UAVs up to 500 is accepted as hobby use.

- Search and rescue activities are not limited with the above-mentioned rules; however, a permission from General Directorateof Civl Aviation is required for the operations.

- All types of UAV flights over the private properties are also required from permission from the owner of the properties.

- Pilots of IHA0 and IHA1 types should be educated until the 01.08.2016. After this day, no pilots can flight those types of UAVs for commercial operations.

\begin{tabular}{|l|l|l|l|l|l|}
\hline $\begin{array}{l}\text { Regulation } \\
\text { clause }\end{array}$ & United States & European Union & China & Turkey & $\begin{array}{l}\text { Recommendation for Turkish } \\
\text { Authorities }\end{array}$ \\
\hline Distance & $\begin{array}{l}\text { Within sight of } \\
\text { operator } \\
\text { during daytime }\end{array}$ & $\begin{array}{l}\text { Within the sight } \\
\text { of operator } \\
\text { during daytime }\end{array}$ & $\begin{array}{l}\text { Within the } \\
\text { sight of the } \\
\text { operator.Must } \\
\text { drive during } \\
\text { the day time. }\end{array}$ & N/A & $\begin{array}{l}\text { Within the sight of operator } \\
\text { (can be waived) }\end{array}$ \\
\hline Max Altitude & $152 \mathrm{~m}$. & $121 \mathrm{mt}$. & $120 \mathrm{~m}$ & N/A & $150 \mathrm{~m}$ \\
\hline Max speed & $161 \mathrm{kmh}$ & $161 \mathrm{kmh}$ & $100 \mathrm{~km} / \mathrm{h}$ & N/A & $150 \mathrm{~km} / \mathrm{h}$ \\
\hline
\end{tabular}




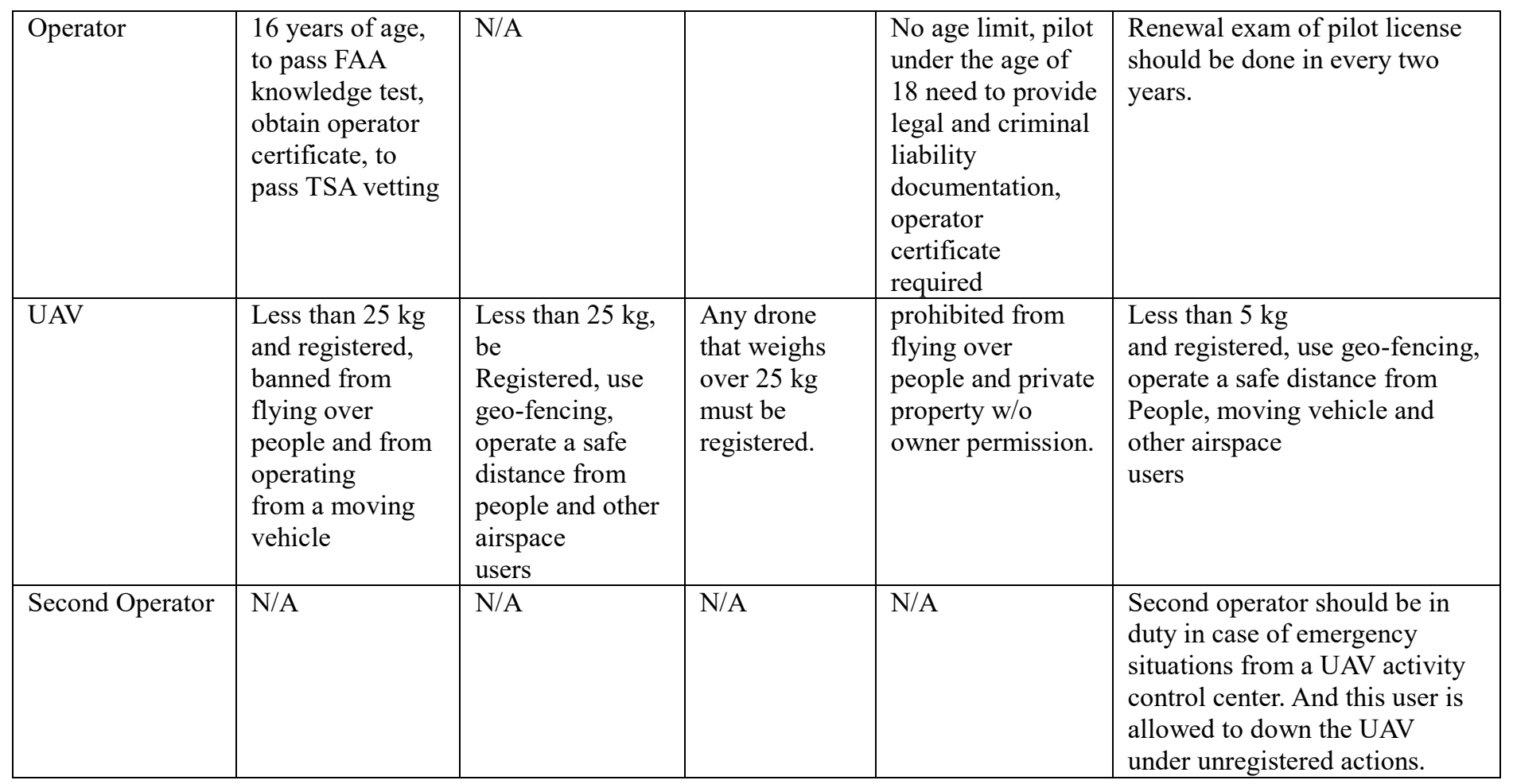

\section{Conclusion}

This paper shows that the use of drone in the construction industry is not a wide solution for improving conventional methodologies. Besides, its usage is limited by many factors such as laws and regulations that are not established sufficiently to relieve concerns. This study can be used as an initial step for improving UAV usage efficiency in construction industry in Turkey. Law and regulation limitations in Turkish standards should be improved by comparing the other updated conditions in all over the world. This will increase the benefits of having UAV's and ease up the construction professional's decision making process by providing accurate upto-date information. Furthermore, health and safety inspections that take time and require to be followed every moment. This will consume huge amount of human resources. Hence, having drones flying over the site can be beneficial.

Education system for UAV operators should be more regulated. Especially, pilot candidate education for IHA0 and IHA1 (commercial purposes) should be held again without any exact final date. This will increase efficienct of UAV use.

Owing to increased number of UVA users, now these machines are part of daily human life. Therefore, they have impact in the social life (Finn \& Wright, 2012). In fact, some researchers are concerned with the possibility of these vehicles might be threat to the public security, which is another point to be investigated(Clarke, 2016) Furthermore, these vehicles might substitute most of the people such as delivery men and consequently have economical impact(Clarke \& Bennett Moses, 2014). In the future studies, researches should investigate that point of UVA's.

\section{References}

Anania, E. C., Rice, S., Pierce, M., Winter, S. R., Capps, J., Walters, N. W., \& Milner, M. N. (2019). Public support for police drone missions depends on political affiliation and neighborhood demographics. Technology in Society, 57(December 2018), 95-103. https://doi.org/10.1016/j.techsoc.2018.12.007

Anwar, Naveed Asian Institute of Technology, Izhar, Muhammad Amir, Kabot Systems Ltd, Najam, Fawad, N. U. of S. and T. (2018). Construction Monitoring and Reporting using Drones and Unmanned Aerial Construction Monitoring and Reporting using Drones and Unmanned Aerial Vehicles ( UAVs ).

Aydin, B. (2019). Public acceptance of drones: Knowledge, attitudes, and practice. Technology in Society, 101180. https://doi.org/10.1016/j.techsoc.2019.101180

Barmpounakis, E. N.,Vlahogianni, E. I.,Golias, J. C. Unmanned Aerial Aircraft Systems for transportation engineering: Current practice and future challenges. International Journal of Transportation Science and Technology, 2016, 5.3: 111-122.

Bognot, J. R., Candido, C. G., Blanco, A. C., Rene, J., \& Montelibano, Y. (2020). Building Construction Progress Monitoring Using Unmanned Aerial System ( UAS ), Low-Cost Photogrammetry, and Geographic Information System ( GIS ), IV(June 2018), 4-7.

Caldas, Carlos H.; Soibelman, Lucio; Gasser, Les. Methodology for the integration of project documents in model-based information systems. Journal of Computing in Civil Engineering, 2005, 19.1: 25-33.

Changali, S., Mohammad, A., \& Nieuwland, M. van. (2015). The construction productivity imperative. 
Chen, Jessie YC. UAV-guided navigation for ground robot tele-operation in a military reconnaissance environment. Ergonomics, 2010, 53.8: 940-950.

Cheung, C., Grocholsky, B.. UAV-UGV Collaboration with a PackBot UGV and Raven SUAV for Pursuit and Tracking of a Dynamic Target. In: SPIE Defense and Security Symposium. International Society for Optics and Photonics, 2008. p. 696216-696216.

Choi, Sungsuk; KIM, Eungkon. Image acquisition system for construction inspection based on small unmanned aerial vehicle. In: Advanced Multimedia and Ubiquitous Engineering. Springer, Berlin, Heidelberg, 2015. p. 273-280.

Clarke, R. (2016). Appropriate regulatory responses to the drone epidemic. Computer Law and Security Review, 32(1), 152-155. https://doi.org/10.1016/j.clsr.2015.12.010

Clarke, R., \& Bennett Moses, L. (2014). The regulation of civilian drones' impacts on public safety. Computer Law and Security Review, 30(3), 263-285. https://doi.org/10.1016/j.clsr.2014.03.007

De Melo, R.R. S, et al. Applicability of unmanned aerial system (UAS) for safety inspection on construction sites. Safety science, 2017, 98: 174-185.

Diaz-Vilarino,L., et al. Determining the limits of unmanned aerial photogrammetry for the evaluation of road runoff. Measurement, 2016, 85: 132-141.

Dix, A., Finlay, J., Abowd, G., and Beale, R. (2004). "Human-computer interaction", (3rd ed.), Prentice-Hall, Inc., 2004.

Heredia, Guillermo, et al. Multi-unmanned aerial vehicle (UAV) cooperative fault detection employing differential global positioning (DGPS), inertial and vision sensors. Sensors, 2009, 9.9: 7566-7579.

Dobson, RJ., Brooks, C, Roussi, C, and Colling, T. "Developing an unpaved road assessment system for practical deployment with high-resolution optical data collection using a helicopter UAV." Proc., Unmanned Aircraft Systems (ICUAS), 2013 International Conference on, Piscataway, NJ. 235-243

Dupont, Quentin FM, et al. Potential Applications of UAV along the Construction's Value Chain. Procedia Engineering, 2017, 182: 165173.

Egan, John, C. T. F. (1998). Rethingking Construction.

Farber, H. B. Eyes in the sky: constitutional and regulatory approaches to domestic drone deployment. 2014.

Finn, R. L., \& Wright, D. (2012). Unmanned aircraft systems: Surveillance, ethics and privacy in civil applications. Computer Law and Security Review, 28(2), 184-194. https://doi.org/10.1016/j.clsr.2012.01.005

Fiorillo, F, Jiménez, B., Remondino, F, \& Barba, S. (2012). 3D surveying and modeling of the archaeological area of Paestum, Italy. Virtual Archaeol Rev, 4, 55-60.

Floreano D, Wood RJ. Science, technology and the future of small autonomous drones. Nature 2015; 521:460-466.
Gheisari,
M, Irizarry,
$\mathrm{J}$, and Walker,

B.

"UAS4SAFETY: The Potential of Unmanned Aerial Systems for Construction Safety Applications." Proc.,

Construction Research Congress 2014, Reston, VA. 1801-1810.

Goedert, J. D.; MeadatiI, P.. Integrating construction process documentation into building information modeling. Journal of construction engineering and management, 2008, 134.7: 509-516.

Han, $\quad$ K, Lin, J, and Golparvar-Fard, $\quad$ M. $\quad$ A Formalism for Utilization of Autonomous VisionBased Systems and Integrated Project Models for Construction Progress Monitoring.” Proc., $\quad 2015 \quad$ Conference on Autonomous and Robotic Construction of Infrastructure

Irizarry, J, Gheisari， M, \& Walker， B. (2012). Usability Assessment of Drone Technology as Safety Inspection Tools. Journal of Information Technology in Construction, 17, 194-212.

Ingham, L. A., Jones, T., and Maneschijn, A.. Considerations for UAV design and operation in South African airspace. The aeronautical journal, 2006, 110.1112: 695-701.

Kavoosi, Z., Raoufat, M. H., Dehghani, M., Abdolabbas, J., Kazemeini, S. A., \& Nazemossadat, M. J. (2018). Feasibility of satellite and drone images for monitoring soil residue cover. Journal of the Saudi Society of Agricultural Sciences. https://doi.org/10.1016/j.jssas.2018.06.001

Kluckner, S, Birchbauer, J-A, Windisch, C, Hoppe, C, Irschara, A, Wendel, A, Zollmann, S, Reitmayr, G, and Bischof, H. “AVSS 2011 demo session: Construction site monitoring from highly-overlapping MAV images." Proc., Advanced Video and Signal-Based Surveillance (AVSS), 2011 8th IEEE International Conference on, Piscataway, NJ. 531-532

Koon M. Construction of Sacramento Kings arena using award-winning drone monitoring system developed at Illinois; 2016.

Lavoie, M. Caterpillar Inc. and Redbird to Advance Work Site Intelligence with Drone Analytics. Caterpillar; 2015.

Lin, J, Han, K, \& Golparvar-Fard, M. (2015). 2015. Proc, Computing in Civil Engineering, 2015, Reston, VA. 156-164.

Nex, Francesco; Remondino, Fabio. UAV for 3D mapping applications: a review. Applied Geomatics, 2014, 6.1: 1-15.

Michael, N, Shen, S, Mohta, K, Kumar, V, Nagatani, K, Okada, Y, Kiribayashi, S, Otake, K, Yoshida, K, Ohno, K, Takeuchi, E, and Tadokoro, $\mathrm{S}$. (2014). "Collaborative Mapping of an Earthquake Damaged Building via Ground and Aerial Robots." Field and Service Robotics, K. Yoshida, and S. Tadokoro, eds., Toronto, Canada: Springer Berlin Heidelberg, 33-47.

Morgenthal, G., Hallerman, N. Quality assessment of Unmanned Aerial Vehicle (UAV) based visual inspection of structures. Advances in Structural Engineering, 2014, 17.3: 289-302.

Okrent, Mark. Civil UAV activity within the framework of European Commission research. In: Proc. of AIAA 3 rd Unmanned Unlimited Technical Conference. 2004. p. 1-12.

Rao, B., Gopi, A. G., \& Maione, R. (2016). The societal impact of commercial drones. Technology in Society, 45, 83-90. https://doi.org/10.1016/j.techsoc.2016.02.009. 
$\mathrm{S}$,

\& Teizer,

J.

(2014).

Mobile

3D mapping for surveying earthwork projects using an Unmanned Aerial Vehicle (UAV) system. Automation in Construction, 41, $1-14$.

Skycatch Inc.'s, https://www.skycatch.com/ (retrieved 20.06.2017).

Xie, F, Lin, Z, Gui, D, \& Lin, H. (2012). Study on construction of 3D building based on UAV images. ISPRS - Int Arch Photogramm Remote Sens Spatial Inform Sci, XXXIX-B1, 469-473

Wakefield, J. Tomorrow's Buildings: Construction industry goes robotic. BBC Technology; 2016.

Wang, G., et al. Risk considerations in the use of unmanned aerial vehicles in the construction industry. 2016.

Wefelscheid, C, Hansch, R, \& Hellwich, O

(2011).

Three-

dimensional building reconstruction using images obtained by unmanned aerial vehicles.

ISPRS

- Int Arch Photogramm Remote Sens Spatial Inform Sci, XXXVIII-1/C22, 183-188.

Wen, M-C, and Kang, S-C. "Augmented Reality and Unmanned Aerial Vehicle Assist in Construction Management.” Proc., Computing in Civil and Building Engineering (2014), Reston, VA. 1570-1577.

Williams, V.. Privacy impact \& the social aspects of public surveillance. Covert Policing Review 2008 .

Yamamoto, T, Kusumoto, H, and Banjo, K. "Data Collection System for a Rapid Recovery Work: Using Digital Photogrammetry and a Small Unmanned Aerial Vehicle (UAV).” Proc., Computing in Civil and Building Engineering (2014), Reston, VA. 875-882

Yang, J, Park, M-W, Vela, P A, \& Golparvar-Fard, M (2015). Construction performance monitoring via still images, time-lapse photos, and video streams: Now, tomorrow, and the future. Advanced Engineering Informatics, 29(2), 211-224

Zhang, J, and Singh, S. "LOAM: Lidar Odometry and Mapping in Real-time." Proc., Robotics: Science and Systems Conference (RSS 2014).

Zollmann, S, Hoppe, C, Kluckner, S, Poglitsch, C, Bischof, H, \& Reitmayr, G. (2014). Augmented Reality for Construction Site Monitoring and Documentation. Proceedings Of the IEEE, 102(2), 137-154. 